\title{
Effect of Varicocelectomy on Restoration of Spermatogenesis in Patients with Non-obstructive Azoospermia
}

\section{Non-obstruktif Azoospermik Erkeklerde Varikoselektominin Spermatogenez Restorasyonuna Etkisi}

\author{
(D) Oktay Özman, (D) Sinharib Çitgez, (D) Fatih Şimşekoğlu, (D) Berin Selçuk, (D) Sami Berk Özden, (D) Hamdi Özkara \\ Istanbul University-Cerrahpaşa, Cerrahpaşa Faculty of Medicine, Department of Urology, Istanbul, Turkiye
}

What's known on the subject? and What does the study add?

The efficiency of varicocelectomy is one of the challenging subject for patients with non-onbstructive azoospermia. In this study, testicular volume and free testosterone levels were found to be predictive factors for recovery of spermatogenesis after varicocelectomy even tough they have a weak association.

\begin{abstract}
Objective: The aim of this study was to investigate the effect of varicocelectomy on spermatogenesis in patients with non-obstructive azoospermia (NOA) and the presence of clinical factors for re-spermatogenesis.

Materials and Methods: A total of 32 patients with clinically significant varicocele, who received the diagnosis of infertility, were included in this study. Microsurgical inguinal varicocelectomy and testicular biopsy were performed in all patients. After varicocelectomy, control spermiogram samples were collected from patients at $3^{\text {rd }}, 6^{\text {th }}$ and $12^{\text {th }}$ months. The role of age, testicular volume, hormone parameters and pathological findings in predicting re-spermatogenesis were investigated.

Results: The mean age of the patients who underwent surgery was $31.4 \pm 6.2$ years. After varicocelectomy, sperm was detected in semen in $15.6 \%$ (5/32) of the patients. As a result of pathological evaluation, hypospermatogenesis, maturation arrest and germ cell aplasia were found in 34.4\%, $31.2 \%$ and $34.4 \%$ of patients, respectively. The testicular volume was higher in patients with re-spermatogenesis $(p=0,01)$. There was no statistically significant difference between responders and non-responders in terms of other investigated parameters.

Conclusion: Varicocelectomy is an acceptable modality of treatment for patients with NOA with clinically significant varicocele. On the other hand, appropriate patient selection is crucial. In this study, testicular volume was found to be a predictive factor for recovery of spermatogenesis after varicocelectomy.
\end{abstract}

Keywords: Infertilty, Non-obstructive azospermia, Varicocelectomy

$\ddot{0 z}$

Amaç: Bu çalışmanın amacı obstruktif olmayan azospermisi (OOA) olan hastalarda varikoselektominin spermatogeneze etkisini incelemek ve respermatogenezi öngören klinik faktörlerin varlığını araştırmaktır.

Gereç ve Yöntem: Klinik anlamlı varikosel saptanarak infertilite tanısı alan 32 hasta çalışmaya dahil edildi. Bütün hastalara mikrocerrahi inguinal varikoselektomi ve aynı seansta testis biyopsisi uygulandı. Postoperatif 3, 6 ve 12. aylarda hastaların spermiyogram kontrolleri yapıldı. Yaş, testis hacmi, hormon parametreleri ve patolojik bulguların operasyon sonrası sperm üretimini öngörmede etkinliği araştırıldı.

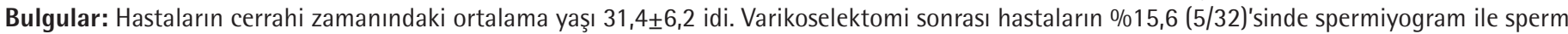
varlığı tespit edildi. Patolojik değerlendirme sonucunda sırasıyla \%34,4, \%31,2 ve \%34,4 oranlarında hipospermatogenez, matürasyon arresti ve germ hücre aplazisi tespit edildi. Re-spermatogenez saptanan hastaların testis hacimleri daha büyüktü ( $p=0.01$ ). Re-spermatogenez saptanan ve saptanmayan hastalar arasında araştırılan diğer parametreler açısından istatistiksel anlamlı fark yoktu.

Sonuç: Varikoselektomi, klinik olarak anlamlı varikoseli olmayan 00A olan hastalarda kabul edilebilir bir tedavi yöntemidir. Diğer taraftan doğru hasta profilinin seçimi çok önemlidir. Bu çalışmada varikoselektomi sonrası spermatogenezin öngörülmesinde testis hacminin prediktif değeri gösterilmiştir.

Anahtar Kelimeler: Infertilite, Obstruktif olmayan azospermi, Varikoselektomi

Correspondence: Sinharib Çitgez MD, İstanbul University-Cerrahpaşa, Cerrahpaşa Faculty of Medicine, Department of Urology, İstanbul, Turkiye Phone: +90 5323122377 E-mail: drsinharib@yahoo.com ORCID-ID: orcid.org/0000-0002-3897-2951

Received: 9.10 .2018

Accepted: 6.12 .2018

Cite this article as: Özman O, Citgez S, Şimşekoğlu F, Selçuk B, Özden SB, Özkara H. Effect of Varicocelectomy on Restoration of Spermatogenesis in Patients with Non-obstructive Azoospermia. J Urol Surg 2019;6(2):130-134.

๑Copyright 2019 by the Association of Urological Surgery / Journal of Urological Surgery published by Galenos Publishing House. 


\section{Introduction}

Varicocele is one of the common causes of male infertility. It is seen in 15\% of the normal population and in $40 \%$ of patients with infertility (1). Varicocelectomy is the most common surgical procedure for infertility. On the other hand, azoospermia is detected in 10-15\% of infertile patients (2). The presence of varicocele is observed in 4-13\% of azoospermic patients (3). This distinct clinical association has led to the idea that varicocele may be the cause of azoospermia and therefore the treatment of azoospermia with varicocelectomy may be possible Tulloch (4) have shown for the first time that sperm can be detected in ejaculate after varicocelectomy in an azoospermic patient with varicocele. Even though half a century has passed after this report had been published, effect of varicocelectomy on patients with non-obstructive azoospermia (NOA) is still controversial. Criteria for decision making whether varicocelectomy should be performed or not for a patient diagnosed with clinically significant varicocele presenting with NOA is still ambiguous (5). It is important to identify patients in whom varicocelectomy will not be effective in order to prevent any delay in obtaining definitive results with assisted reproductive techniques. Clinical parameters are needed to help effective patient selection. Testicular biopsy may provide parameters for this purpose. Aboutaleb et al. (2) showed that patients with hypospermatogenesis were more likely to benefit from varicocelectomy. The predictive value of age, testicular volume and hormonal parameters, such as follicle stimulating hormone (FSH), luteinizing hormone (LH) and total testosterone (T), has also not yet fully revealed. The aim of this study was to investigate the effect of varicocelectomy on spermatogenesis in NOA azoospermic patients and the presence of clinical factors for re-spermatogenesis.

\section{Materials and Method}

After the ethics committee approval (ethical committee approval number: 83045809/604.01/02-171680), this prospective study including 32 patients prediagnosed with infertility presenting with varicocele and NOA was conducted between January 2016 and June 2018 in Cerrahpaşa Medical Faculty. The diagnosis of azoospermia was made by at least two spermiograms made by the same biologist. None of the patients had physical examination and imaging findings in favor of obstruction. Spermiogram samples were collected after a 3 days sexual abstinence. There were 3 weeks between two spermiograms. The absence of sperm cells in centrifuged pellets was accepted as azoospermia. In addition, the patients were examined for the presence of clinically significant varicocele according to the World Health Organization criteria. Every patient in the study was examined by two different urologist for the presence of varicocele. Bilateral varicocele was considered high-grade varicocele. Genetic evaluation was performed in all patients in accordance with the current European Urology Association guidelines for male infertility. Karyotype analysis and $Y$ chromosome microdeletion assays were done. Serum levels of $\mathrm{FSH}, \mathrm{LH}$ and $\Pi \mathrm{T}$ were measured. Bilateral testicular volumes were determined by scrotal ultrasonography.

After the surgical intervention, control spermiogram samples at $3^{\text {rd }}, 6^{\text {th }}$ and $12^{\text {th }}$ months were examined by the medical biologist who made the preoperative evaluation. The patients were divided into two groups according to the presence of sperm in the spermiogram after varicocelectomy. Two groups were compared in terms of age, testicular volume, $\mathrm{FSH}, \mathrm{LH}, \Pi$ and pathological findings.

\section{Surgical Technique}

Inguinal microsurgical varicocelectomy and testicular biopsy procedures were performed in all patients. A 3-cm skin incision was made in the groin region. After fascia incision, the spermatic cord was elevated with a Babcock clamp. A surgical microscope (Leica Microsystems ${ }^{\odot}$ ) was used for microsurgical technique. Dilated spermatic veins were ligated and transected. Lymphatics and arteries were preserved. Testicular biopsy was performed at the same session. The scrotal layers were dissected until the tunica albugine was reached. A $1-\mathrm{cm}$ transverse incision was performed on the anterior scrotal skin. and the testicular tissue was excised. All biopsies were evaluated by the same uropathologist.

\section{Statistical Analyses}

Student's t-test and chi-square test were used for univariate statistical analyses of the collected data. The data was analyzed with the Statistical Package for the Social Sciences v. 16 (SPSS Inc, Illinois, USA). A p value of less than 0.05 was considered statistically significant.

Table 1. Characteristics of patients

\begin{tabular}{lllll}
\hline Characteristic & $\begin{array}{l}\text { All } \\
(\mathbf{n}=\mathbf{3 2})\end{array}$ & $\begin{array}{l}\text { Responders } \\
(\mathbf{n}=5)\end{array}$ & $\begin{array}{l}\text { Non- } \\
\text { responders } \\
(\mathbf{n = 2 7})\end{array}$ & $\mathbf{p}$ \\
\hline Age (year) & $31.4 \pm 6.2$ & $29.8 \pm 5.8$ & $31.7 \pm 6.2$ & 0.52 \\
\hline $\begin{array}{l}\text { Testis volume } \\
(\mathrm{mL})\end{array}$ & - & - & - & - \\
\hline Right & $7.5 \pm 3.4$ & $9.4 \pm 3.5$ & $7.2 \pm 3.4$ & 0.09 \\
\hline Left & $6.9 \pm 3.5$ & $10.0 \pm 3.6$ & $6.4 \pm 3.5$ & 0.01 \\
\hline FSH (mIU/mL) & $17.9 \pm 11.9$ & $15.2 \pm 13.8$ & $18.6 \pm 11.9$ & 0.56 \\
\hline LH (mIU/mL) & $8.4 \pm 3.6$ & $7.4 \pm 4.5$ & $8.6 \pm 3.6$ & 0.51 \\
\hline $\begin{array}{l}\text { Total } \\
\begin{array}{l}\text { Testosteron } \\
\text { (ng/dL) }\end{array}\end{array}$ & $414.1 \pm 210.5$ & $405.5 \pm 185.6$ & $440.3 \pm 210.5$ & 0.66 \\
\hline
\end{tabular}

FSH: Follicle-stimulating hormone, LH: Luteinizing hormone 


\section{Results}

The mean age of the patients at the time of surgery was $31.4 \pm 6.2$ years. The mean testicular volume and hormone profiles of the patients are summarized in Table 1. When the patients were divided into two groups according to the presence of sperm in postoperative spermiograms, a statistically significant difference was found between the two groups in terms of median left and right testicular volume ( $p=0.01$ and $p=0.09$, respectively). Patients with recovery of spermatogenesis were found to have higher testicular volume. There was no statistically significant difference in age, $\mathrm{FSH}, \mathrm{LH}$ and $\mathrm{TT}$ levels between responders and non-responders.

Grade 1, 2 and 3 varicocele was detected in 10 (31.3\%), 19 $(59.2 \%)$ and $3(9.3 \%)$ patients, respectively. Bilateral varicocele was found in $34.4 \%$ of patients (11/32). One patient had rightsided, and the rest of the patients had left-sided varicocele. Two patients had secondary infertility and 5 patients had recurrent varicocele. The detailed varicocele examination findings of the patients are shown in Table 2. Two patients had a history of unilateral orchiectomy. Re-spermatogenesis was not observed after varicocele repair in these two patients. The only patient who underwent right varicocelectomy had a history of left orchiectomy.

Pathological examinations of the testicular biopsy specimens revealed hypospermatogenesis, maturation arrest and germ cell aplasia in $34.4 \%, 31.2 \%$ and $34.4 \%$ of patients, respectively. There was no statistically significant difference in pathological diagnosis between the responders and non-responders (Table 3).

There were no postoperative and peroperative complications associated with varicocelectomy performed concurrently with testicular biopsy. Patients were followed for 12 months postoperatively. During this follow-up period, the spermiogram samples have yielded that $15.6 \%$ (5/32) patients had recovery of spermatogenesis. Re-spermatogenesis rates in $3^{\text {rd }}, 6^{\text {th }}$ and

Table 2. Varicocele grades of groups

\begin{tabular}{lllll}
\hline Characteristic & Grade 1 & Grade 2 & Grade 3 & p \\
\hline $\begin{array}{l}\text { Number of } \\
\text { patients }(n=32)\end{array}$ & $10(31.3 \%)$ & $19(59.4 \%)$ & $3(9.3 \%)$ & - \\
\hline Responders $(n=5)$ & $0(0 \%)$ & $5(100 \%)$ & $0(0 \%)$ & 0.52 \\
\hline $\begin{array}{l}\text { Non-responders } \\
(n=27)\end{array}$ & $10(37 \%)$ & $14(51.8 \%)$ & $3(11.2 \%)$ & - \\
\end{tabular}

$12^{\text {th }}$ months were $9 \%, 12.5 \%$ and $15.6 \%$, respectively. Amongst these patients, 1 patient had hypospermatogenesis, 2 patients had maturation arrest and 2 patients had germ cell aplasia.

\section{Discussion}

Currently, there is no known medical or surgical treatment for idiopathic azoospermia. Men with azoospermia due to spermatogenic failure can only have children with the help of surgical methods and assisted re-productive techniques. Varicocele is common in the community and varicocelectomy is the most common surgical intervention for varicoceleassociated infertility (1). The coexistence of these two clinical conditions makes varicocelectomy a treatment option for azoospermia.

Matthews et al. (6) reported the presence of motile sperm in the ejaculate after varicocelectomy in 55\% of 22 patients with azoospermia. Gat et al. (7) have shown that varicocelectomy may spare in more than 50\% of azoospermic patients the need for testicular sperm extraction as preparation for intracytoplasmic sperm injection. In their study including 31 males, only 9.6\% of patients had adequate motile sperm in the ejaculate after varicocelectomy (8). In a systematic review and meta-analysis of 468 NOA patients who underwent varicocelectomy, it was reported that sperm was found in postoperative ejaculates in $43.9 \%$ of 344 patients (9). In our study, sperm was detected in ejaculate in $15.6 \%$ of patients (5/32).

Conflicting data on the relationship between varicocele grade and postoperative re-spermatogenesis suggests that the relationship between varicocele and azoospermia may be more complex. Probably the toxic effects of varicocele over time reach a plateau where the restoration potential of spermatogenesis is completely eliminated. The high rates of re-spermatogenesis obtained by Matthews et al. (6) can be explained by the high grade and bilateral varicocele in the series. The rate of re-spermatogenesis in a study by Zampieri et al. (10), which only included azoospermic patients with grade 3 varicocele, was similar to that in the above study. In our series, only 3 patients had grade 3 varicocele, and the bilaterality rate was low (34.4\%). It is deduced that sperm detection in our study would be lower than in other studies due to that particular reason. On the other hand, there are studies suggesting that there is no relationship between varicocele degree and postvaricocelectomy re-spermatogenesis $(11,12)$. Finally, a meta-

Table 3. Pathological findings

\begin{tabular}{lllll}
\hline Pathological diagnosis & All $(\mathbf{n}=\mathbf{3 2})$ & Responders $(\mathbf{n}=\mathbf{5})$ & Non-responders $(\mathbf{n}=\mathbf{2 7})$ & $\mathbf{p}$ value \\
\hline Hypospermatogenesis & $11(34.4 \%)$ & $1(20 \%)$ & $10(37 \%)$ & - \\
\hline Maturation arrest & $10(31.2 \%)$ & $2(40 \%)$ & $8(29.6 \%)$ & 0.76 \\
\hline Sertoli cell only & $11(34.4 \%)$ & $2(40 \%)$ & $9(33.4 \%)$ & -
\end{tabular}


analysis of the data of five different studies showed that the rate of postoperative sperm retrieval was not increased with increasing varicocele grade. Varicocele may just be an incidental finding rather than an etiological element for most of the cases (5). Therefore, for appropriate patient selection, the parameters of the spermatogenic failure caused by varicocele should be enlightened.

In studies examining the relationship between NOA and varicocelectomy, certain predictive factors have been thoroughly researched. In the literature, some of the studies suggested that patients with a high level of FSH may not benefit from varicocelectomy (13). Ishikawa et al. (11) has conjectured that FSH was not a reliable parameter for predicting the outcome of varicocelectomy. In our study, lower FSH levels were found in patients who had viable sperms in their ejaculates after the surgery. However, no statistically significant difference was found in mean FSH levels between the two groups $(p=0.56)$. Similarly, other hormonal parameters did not show a significance to be used as predictive factors in future studies. Aboutaleb et al. (2) found no correlation between serum LH and $\Pi$ levels and re-spermatogenesis after varicocelectomy. Similar results were obtained in our study.

The predictive value of testicular volume was also frequently investigated. In a study including NOA patients with grade 2 and 3 varicocele, no statistically significant relationship was found between post-varicocelectomy sperm production and testicular volume (14). Similar findings were found in a meta-analysis conducted in 2010 (15). Unlike reported cases in the literature, the testicular volume was higher in the re-spermatogenesis group compared to non-responder group in our study ( $p=0.01$ ).

In their meta analysis, Esteves et al. (9) reported that in 8 of the included studies, in a total of 161 patients, the rate of positive postoperative ejaculate in hypospermatogenesis patients was found to be statistically higher compared to those with sertoli cell only and maturation arrest. It was emphasized that the only prognostic factor to consistently predict obtaining viable sperm in an ejaculate collected after varicocelectomy was testicular histopathology. Amongst the patients responding to varicocelectomy in our study, 1 had histospermatogensis, 2 had maturation arrest and 2 had germ cell aplasia. However, there was no statistically significant difference in pathological diagnosis between the responders and non-responders $(p=0.76)$.

\section{Study Limitations}

In this study, we researched the effect of varicocelectomy on spermatogenesis in patients diagnosed with NOA and we defined the predictive factors favorable for recovery of spermatogenesis. Even though testicular pathology is found to be a relatively stronger predictive factor it is not always possible to obtain biopsy samples manifesting the sperm production in the whole testes. Our study has certain limitations. Firstly, the number of patients was limited. Furthermore, the relatively low number of patients with advanced varicocele made it difficult to demonstrate the relationship between azoospermia and varicocele. Also it should not be forgotten that the number of studies performed on that particular patient group are few in the literature. In short, we believe that the results of this study will contribute to the literature. Future large-scale prospective studies are warranted.

\section{Conclusion}

Varicocelectomy is an acceptable modality of treatment for non-obstructive azoospermic patients with clinically significant varicocele. On the other hand, appropriate patient selection is crucial. In this study, testicular volume was found to be a predictive factor for recovery of spermatogenesis after varicocelectomy.

\section{Ethics}

Ethics Committee Approval: Ethical committee approval was given by Cerrahpaşa Medical Faculty (approval number: 83045809/604.01/02-171680).

Informed Consent: Consent form was filled out by all participants.

Peer-review: Internally peer-reviewed.

\section{Authorship Contributions:}

Surgical and Medical Practices: S.Ç., H.Ö., Concept: S.Ç., H.Ö., 0.Ö., Design: 0.Ö., S.Ç., Data Collection or Processing: M.F.Ş., S.B.Ö., B.S., Analysis or Interpretation: S.Ç., 0.Ö., M.F.Ş., Literature Search: B.S., O.Ö., Writing: S.Ç., M.F.Ş., H.Ö., 0.Ö.

Conflict of Interest: No conflict of interest was declared by the authors.

Financial Disclosure: The authors declared that this study received no financial support.

\section{References}

1. Gorelick Jl, Goldstein M. Loss of fertility in men with varicocele. Fertil Steril 1993;59:613-616.

2. Aboutaleb HA, Elsherif EA-R, Omar MK, Abdelbaky TM. Testicular Biopsy Histopathology as an Indicator of Successful Restoration of Spermatogenesis after Varicocelectomy in Non-obstructive Azoospermia. The World Journal of Men's Health 2014;32:43-49.

3. Czaplicki M, Bablok L, Janczewski Z. Varicocelectomy in patients with azoospermia. Archives of andrology 1979;3:51-55.

4. Tulloch WS. A consideration of sterility factors in the light of subsequent pregnancies. II. Sub fertility in the male. (Tr. Edinburgh Obst. Soc. Session 104). Edinburgh medical journal 1951;59:29-34. 
5. Chiba K, Fujisawa M. Clinical Outcomes of Varicocele Repair in Infertile Men: A Review. World J Mens Health 2016;34:101-109.

6. Matthews GJ, Matthews ED, Goldstein M. Induction of spermatogenesis and achievement of pregnancy after microsurgical varicocelectomy in men with azoospermia and severe oligoasthenospermia. Fertility and Sterility 70:7175.

7. Gat Y, Bachar GN, Everaert K, Levinger U, Gornish M. Induction of spermatogenesis in azoospermic men after internal spermatic vein embolization for the treatment of varicocele. Human Reproduction 2005;20:1013-1017.

8. Schlegel PN, Kaufmann J. Role of varicocelectomy in men with nonobstructive azoospermia. Fertility and Sterility 81:1585-1588.

9. Esteves SC, Miyaoka R, Roque M, Agarwal A. Outcome of varicocele repair in men with nonobstructive azoospermia: systematic review and metaanalysis. Asian J Androl 2016;18:246-253.

10. Zampieri N, Bosaro L, Costantini C, Zaffagnini S, Zampieri G. Relationship between testicular sperm extraction and varicocelectomy in patients with varicocele and nonobstructive azoospermia. Urology 2013;82:74-77.
11. Ishikawa $T$, Kondo $Y$, Yamaguchi $K$, Sakamoto $Y$, Fujisawa M. Effect of varicocelectomy on patients with unobstructive azoospermia and severe oligospermia. BJU Int 2008;101:216-218.

12. Braedel HU, Steffens J, Ziegler M, Polsky MS, Platt ML. A possible ontogenic etiology for idiopathic left varicocele. J Urol 1994;151:62-66.

13. Micic S, Illic V, Isvaneski M. Correlation of hormone and histologic parameters in infertile men with varicocele. Urologia internationalis 1983;38:187-190.

14. D'Andrea S, Giordano AV, Carducci S, Sacchetti L, Necozione S, Costanzo M, et al. Embolization of left spermatic vein in non-obstructive azoospermic men with varicocele: role of FSH to predict the appearance of ejaculated spermatozoa after treatment. Journal of endocrinological investigation 2015;38:785-790.

15. Weedin JW, Khera M, Lipshultz LI. Varicocele repair in patients with nonobstructive azoospermia: a meta-analysis. J Urol 2010;183:2309-2315. 